\title{
COMMUNICATION
}

Cite this: DOI: $10.1039 / \times 0 \times x 00000 x$

\section{Identification of a novel class of Autotaxin inhibitors through cross-screening.}

\author{
Diana Castagna, ${ }^{\mathrm{a} \ddagger}$ Emma L. Duffy, ${ }^{\mathrm{a} \ddagger}$ Dima Semaan, ${ }^{\mathrm{b}}$ Louise C. Young, ${ }^{\mathrm{b}}$ John M. \\ Pritchard, ${ }^{\mathrm{c}}$ Simon J. F. Macdonald, ${ }^{\mathrm{c}}$ David C. Budd, ${ }^{\mathrm{c}}$ Craig Jamieson, ${ }^{\mathrm{a}}{ }^{*}$ and Allan J. \\ B. Watson ${ }^{\text {a* }}$
}

Received 00th January 2012, Accepted 00th January 2012

DOI: $10.1039 / \times 0 \times x 00000 x$

www.rsc.org/

Three novel series were generated in order to mimic the pharmacophoric features displayed by lead compound AM095, a Lysophosphatidic acid $\left(\mathrm{LPA}_{1}\right)$ receptor antagonist. Biological evaluation of this array of putative $\operatorname{LPA}_{1}$ antagonists led us to the discovery of three novel series of inhibitors of the ecto-enzyme Autotaxin (ATX), responsible for LPA production in blood, with potencies in the range 1 $4 \mu \mathrm{M}$ accompanied with $\operatorname{good}(>100 \mu \mathrm{g} / \mathrm{mL})$ solubility.

\section{Introduction}

Lysophosphatidic acid (LPA) is a bioactive phospholipid, accessed via the hydrolysis of lysophosphatidyl choline (LPC) by the enzyme Autotaxin $(\mathrm{ATX})^{1,2}$ and mediates most of its biological effects through a set of six G-protein-coupled receptors (GPCRs) known as $\mathrm{LPA}_{1-6}{ }^{3}$ These receptors induce a number of downstream signalling pathways and exert a range of cellular responses such as calcium mobilisation, transformation of smooth muscle cells, cell proliferation and migration, prevention of apoptosis, and chemotaxis through acting as agonists at membrane-bound GPCRs. ${ }^{4}$ Based on this, the ATX-LPA signalling pathway has been implicated in many disease states including cardiovascular disease, ${ }^{5}$ autoimmune disease, ${ }^{6}$ cancer, ${ }^{7}$ fibrotic diseases, ${ }^{8}$ inflammation, ${ }^{9}$ neurodegeneration, ${ }^{10}$ and pain, ${ }^{11}$ amongst others. Accordingly, significant efforts have been invested in the generation of novel lead compounds in order to identify new chemotypes for the treatment of LPA/ATX-related disorders. A recent review has summarised the current state of lysophospholipid receptors in drug discovery. ${ }^{12}$ Among the first LPAR antagonists synthesised were lipid like structures, ${ }^{13,14}$ similarly the first patent describing ATX inhibitors were also lipid-like. ${ }^{15}$ As both $\mathrm{LPA}_{1}$ and ATX bind LPA, one might expect a degree of cross-talk between the types of compound which interact with both targets. This phenomenon has been reported with syn- and anti- diastereomers of $\alpha$-bromophosphonates (BrP-LPA); pan-LPA $\mathrm{L}_{1-3}$ antagonists and nanomolar inhibitors of ATX. ${ }^{16}$ However, these lipid-like compounds are suboptimal drug development candidates, as their physicochemical profiles do not meet conventional medicinal chemistry requirements, as they exhibit high molecular weight and lipophilicity, two factors which are associated with attrition in drug development. ${ }^{17}$ The first non-lipid like structure acting as an LPA receptor antagonist was Ki16425. ${ }^{18}$ This was identified through screening of 150,000 low molecular weight compounds by the Kirin Brewery for LPA receptor antagonism. It was found that the isoxazole derivative Ki16425(1) inhibited LPA-induced actions in a manner highly specific to $\mathrm{LPA}_{1}$ and $\mathrm{LPA}_{3}$ receptor subtypes. ${ }^{18}$ Subsequently, AM095(4), a novel $\mathrm{LPA}_{1}$ receptor antagonist originally developed by Amira Pharmaceuticals Inc., and accompanied by Bristol-Myers Squibb, was developed. Further classes of $\mathrm{LPA}_{1}$ receptor antagonists have been disclosed, most recently from Hoffmann-La Roche. ${ }^{3}$ In order to identify novel $\mathrm{LPA}_{1}$-selective antagonists, Hoffmann-La Roche undertook a bioisostere approach based on the AM095 scaffold, and reported the synthesis and biological testing of a novel class of $\mathrm{LPA}_{1}$ antagonists. ${ }^{3}$ Of the reported chemotypes, AM095 has progressed to clinical trials and as a result became the main focus of our current study. Herein, we report the design and synthesis of a novel palette of compounds, derived from the AM095 chemotype which display inhibitory activity in the ATX/LPA pathway.

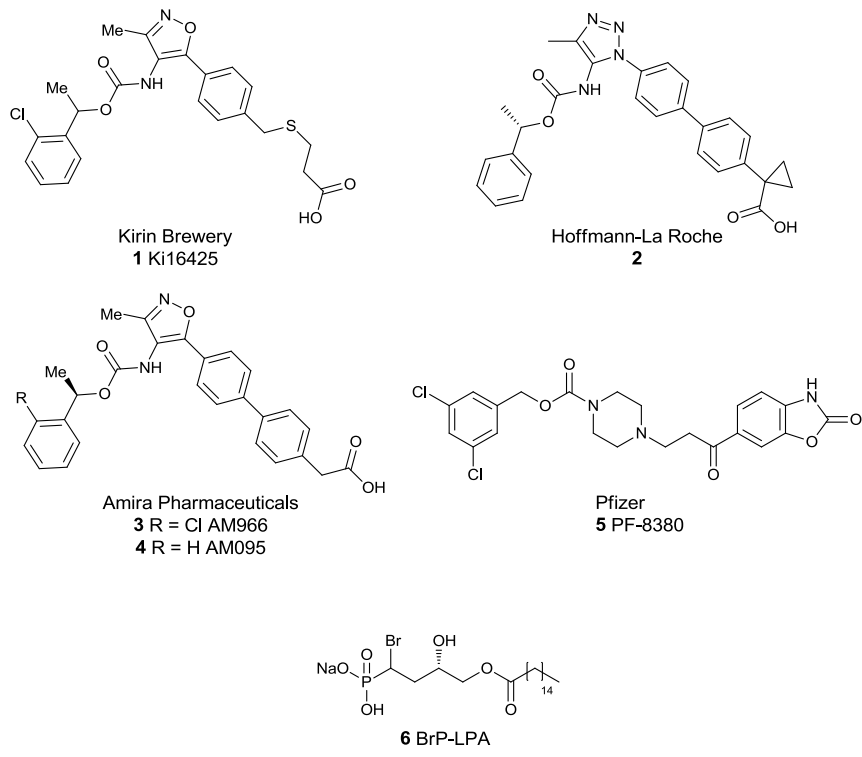


Figure 1. Selected $\mathrm{LPA}_{1}$ antagonists 1-4, ATX inhibitor 5, and pan$\mathrm{LPA}_{1-3}$ antagonist/ATX inhibitor 6

\section{Compound Design and Synthesis}

The medicinal chemistry strategy implemented was a scaffold hopping approach in order to identify a new chemotype based on the Amira (AM095) and Hoffmann-La Roche assets which belong to the same pharmacophore. To this end, three unique series were designed by performing simple disconnections to give the acyl aniline, the aryl indole, and the hydantoin series, removing the isoxazole as it was assumed to be a non-essential spacer, as illustrated in Scheme 1. The acyl aniline and the hydantoin series retained the carbamate, biphenyl acetic acid moieties present in AM095 whilst the aryl indole series challenged this binding hypothesis with the construction of a series containing a similar structural overlap but different functionalities. In addition to the representative examples depicted, the regiochemistry of the biaryl and acetic acid moiety would be probed. The aim of the three series was to design a "reduced complexity' (lead-like)19 library using simple synthetic handles available for chemical synthesis.

In order to qualitatively asses the level of similarity between AM095 and the three proposed series, a range of overlays were prepared using energy minimized structures of AM095 and an exemplar from each series. These were generated using Gaussian ${ }^{20}$ programme and then manually overlayed using Discovery Visualiser, ${ }^{21}$ as efficient overlap may be indicative of a similar binding mode. These novel heterocyclic biaryl compounds could potentially provide selectivity toward LPAR isoforms. Based on the analysis shown in Scheme 1 all compounds demonstrated a reasonable degree of overlap with AM095, and accordingly, these templates were prioritised for synthesis in order to validate their biological properties against both LPA receptors and Autotaxin.

The synthetic approach used for the construction of the acyl aniline and the aryl indole series is illustrated in Schemes 2 and 3, respectively. The acyl aniline series was divided into three main routes in order to probe: (i) the position of the acetic acid moiety; (ii) the presence of the acetic acid moiety; and (iii) the potential for functionalization on the nitrogen of the aniline in the form of a cyclohexyl (c-Hex) or a tetrahydropyran (THP) group to mimic the isoxazole group present in AM095. The synthetic route associated with each of these three subgroups involved the use of three main steps: (i) carbamate formation; (ii) Suzuki-Miayura cross-coupling; and (iii) hydrolysis. Compounds 7, 16, and 17 were synthesised by reaction of 3-bromoaniline with benzyl chloroformate to afford carbamate 11, which could then be taken forward into the SuzukiMiayura cross-coupling, using a range of substituted pinacol boronic esters to install the desired biaryl functionality.

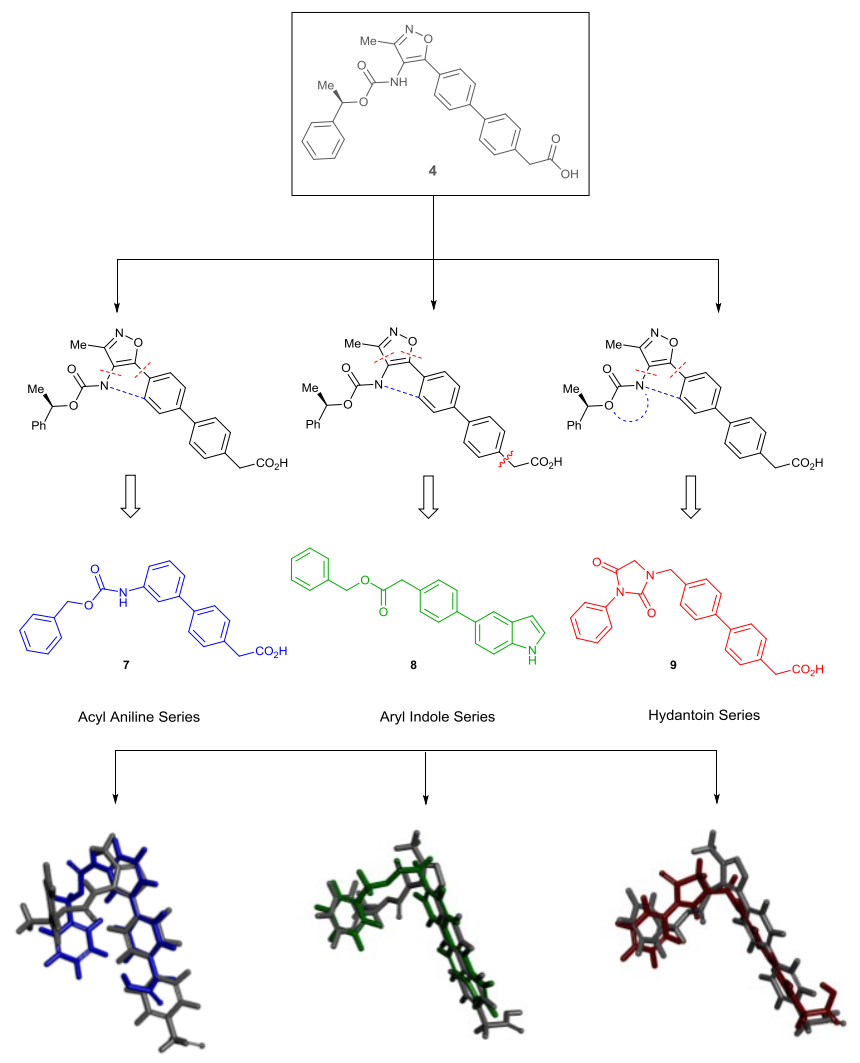

Scheme 1. Schematic representation of the three proposed series (79) from disconnecting AM095 and their corresponding overlays with AM095 (grey).

The final step involved the hydrolysis of the ester moiety to afford the desired acetic acid compounds. A similar route was followed for the formation of compound $\mathbf{1 5}$, which involved the reaction of phenyl boronic acid with compound $\mathbf{1 1}$ in order to obtain the biaryl species lacking the acetic acid moiety. Lastly, substitution was introduced on the nitrogen of the aniline by reductive amination of 10 with cyclohexanone and tetrahydropyranone, followed by the carbamate formation using benzyl chloroformate, and, finally, hydrolysis to reveal the acetic acid moiety for compounds $\mathbf{2 5}$ and $\mathbf{2 6 .}$

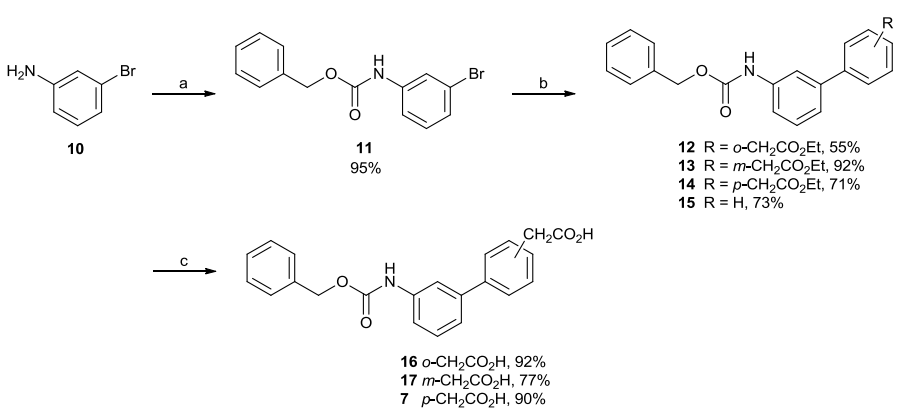

Scheme 2. Route developed for the synthesis of acyl aniline compounds. a) $\mathrm{K}_{2} \mathrm{CO}_{3}, \mathrm{CbzCl}, 2-\mathrm{MeTHF}, \mathrm{rt}, 5 \mathrm{~h}$; b) 2'(dimethylamino)-2-biphenylyl-palladium(II)chloride dinorbornylphosphine complex, $\mathrm{K}_{3} \mathrm{PO}_{4}$, pinacol boronic ester, 1,4dioxane/water $(2: 1), 130{ }^{\circ} \mathrm{C}, 30 \mathrm{~min}, \mu \mathrm{W}$; c) $\mathrm{NaOH}$, THF, $16 \mathrm{~h}, 40$ ${ }^{\circ} \mathrm{C}$. 

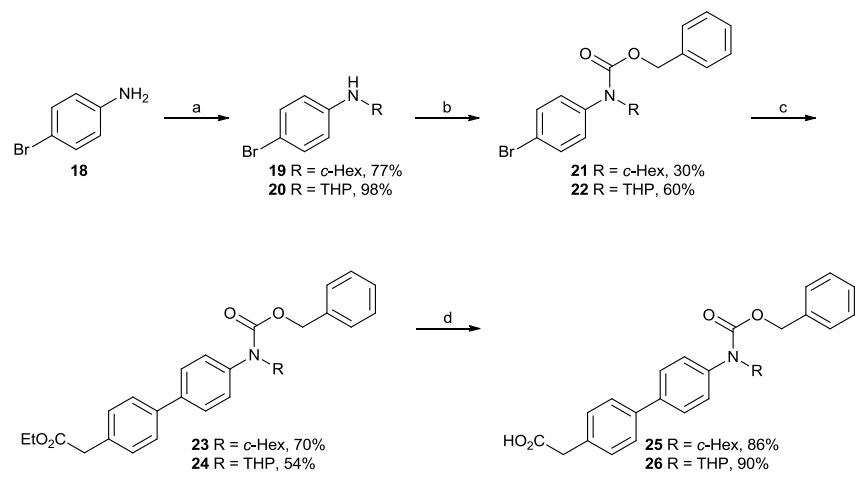

Scheme 3. Route developed for the synthesis of the substituted acyl aniline compounds. a) $\mathrm{NaHB}(\mathrm{OAc})_{3}, \mathrm{DCE}, \mathrm{AcOH}, \mathrm{rt}, 24 \mathrm{~h}$, cyclohexanone or tetrahydropyranone; b) $\mathrm{K}_{2} \mathrm{CO}_{3}, \mathrm{CbzCl}$, DCE, rt, 24 h; c) 2'-(dimethylamino)-2-biphenylyl-palladium(II)chloride dinorbornylphosphine complex, $\mathrm{K}_{3} \mathrm{PO}_{4}$, pinacol boronic ester, 1,4dioxane/water $(2: 1), 130{ }^{\circ} \mathrm{C}, 30 \mathrm{~min}, \mu \mathrm{W}$; d) $\mathrm{NaOH}, \mathrm{THF}, 16 \mathrm{~h}, 40$ ${ }^{\circ} \mathrm{C}$.

A similar route was undertaken for the synthesis of the aryl indole compounds, illustrated in Scheme 4. However, hydrolysis of the benzylic ester to the acetic acid was performed prior to the introduction of the carbamate.
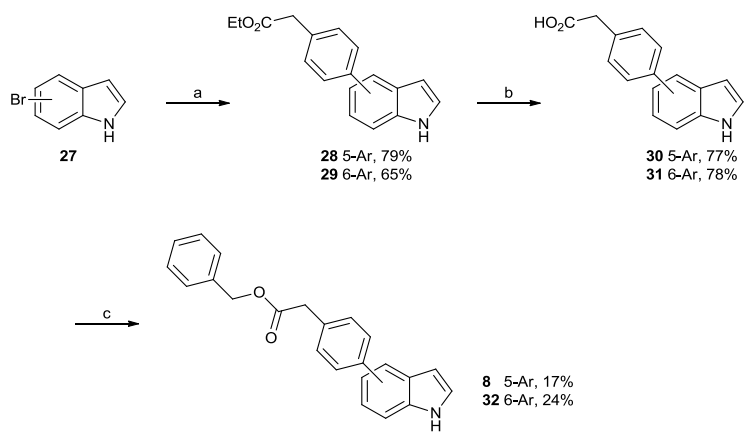

Scheme 4. Route developed for the synthesis aryl indole compounds. $\quad$ a) '-(Dimethylamino)-2-biphenylylpalladium(II)chloride dinorbornylphosphine complex, $\mathrm{K}_{3} \mathrm{PO}_{4}$, pinacol boronic ester, 1,4-dioxane/water $(2: 1), 130{ }^{\circ} \mathrm{C}, 30 \mathrm{~min}, \mu \mathrm{W}$; b) $\mathrm{NaOH}, \mathrm{THF}, \quad 40{ }^{\circ} \mathrm{C}, 16 \mathrm{~h} ;$ c) $\mathrm{NaH}, \mathrm{DMF}, \mathrm{N}-$ (Benzyloxycarbonyloxy)succinimide, $40{ }^{\circ} \mathrm{C}, 16 \mathrm{~h}$.

The hydantoins series was accessed via two main routes (i) benzyl hydantoin, and (ii) pyridyl hydantoin. The phenyl substituted hydantoin possessed good structural overlay with AM095, therefore the isopropyl $(i$-Pr) and cyclohexyl ( $c$-Hex) groups were designed as isosteres to the phenyl group with the goal of lowering clogP and reducing the number of aromatic rings to below three. ${ }^{22}$ Within the benzyl hydantoin the presence/absence of the acetic acid would be probed along with cyclopropyl substitution alpha to the carboxylic acid. The synthetic route applied to the hydantoin series is illustrated in Schemes $\mathbf{5}$ and 6. The construction of this series required firstly the synthesis of the requisite hydantoin intermediates using reductive amination, of both 2-(4-bromophenyl)acetaldehyde and 5-bromo picolinaldehyde to the secondary amines 34 and 43. Preparation of the target hydantoins involved the reaction of the appropriate secondary amine with the relevant isocyanate system, yielding a urea derivative. This derivative is not isolated but can be readily converted to the hydantoin following treatment with a protic acid, in this case, trifluoroacetic acid. This was applied to the synthesis of

compounds 35-37 (Scheme 5), and 44-45 (Scheme 6). SuzukiMiyaura cross-coupling was used to prepare the biaryl hydantoins with boronic pinacol esters and then smoothly hydrolysed to the acetic acid functionality, furnishing compounds 9, 38-41 and 46-47.

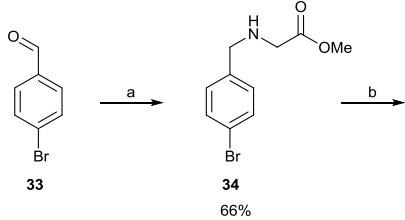

Scheme 5. Route developed for the synthesis of the hydantoin compounds. a) Glycine methyl ester hydrochloride, EtOH, $\mathrm{NEt}_{3}$, $\mathrm{MeOH}, \mathrm{NaBH}_{4}, \mathrm{rt}, 2 \mathrm{~h}$; b) $\mathrm{CH}_{2} \mathrm{Cl}_{2}$, isocyanate, TFA; c) Pinacol boronic ester, $\mathrm{Pd}_{2}(\mathrm{dba})_{3}, \mathrm{PCy}_{3}, \mathrm{~K}_{3} \mathrm{PO}_{4}, 1,4$-dioxane $/ \mathrm{H}_{2} \mathrm{O}$ (1.3:0.7), $100{ }^{\circ} \mathrm{C}, 16 \mathrm{~h}$; d) $\mathrm{THF} / \mathrm{H}_{2} \mathrm{O}(3: 1), \mathrm{LiOH}, \mathrm{rt}, 3 \mathrm{~h}$.

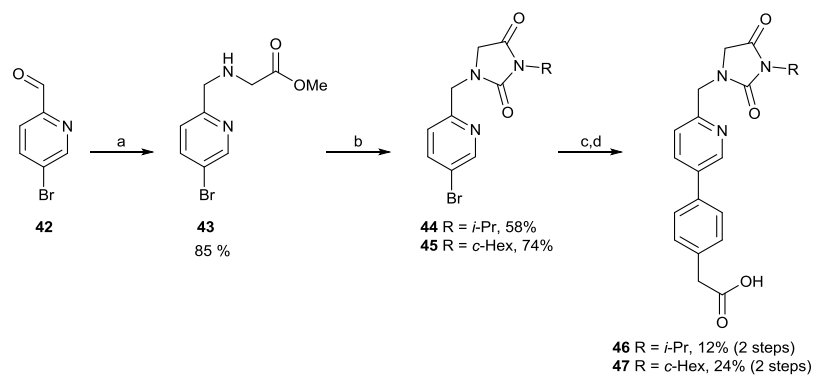

Scheme 6. Route developed for the synthesis of the pyridine hydantoin compounds. a) Glycine methyl ester hydrochloride, $\mathrm{MeOH}, \mathrm{NEt}_{3}, \mathrm{NaBH}(\mathrm{OAc})_{3}$; b) $\mathrm{CH}_{2} \mathrm{Cl}_{2}$, isocyanate, TFA; c) 2'(dimethylamino)-2-biphenylyl-palladium(II)chloride

dinorbornylphosphine complex, $\mathrm{K}_{3} \mathrm{PO}_{4}, \quad$ 4-(carboxymethyl) phenylboronic acid pinacol ester, 1,4-dioxane/water $(2: 1), 100{ }^{\circ} \mathrm{C}$, $16 \mathrm{~h}$; d) $\mathrm{THF} / \mathrm{H}_{2} \mathrm{O}$ (3:1), $\mathrm{LiOH}, \mathrm{rt}, 3 \mathrm{~h}$.

\section{Pharmacology}

The synthesised compounds were evaluated for both $\mathrm{LPA}_{1}$ receptor agonism and antagonism using CHO-K1 EDG2 $\beta$-Arrestin cell line in a single dose format $(10 \mu \mathrm{M})$, with the inclusion of 1-oleoylLPA, AM095, and Ki16425 as controls. ${ }^{23}$ The data obtained from the assay is described in terms of a percentage of agonism where $100 \%$ refers to complete agonism and $0 \%$ refers to complete antagonism. The data obtained from this assay unfortunately indicated that none of the synthesised compounds were acting as LPA agonists, and in terms of antagonist activity only the controls, 1-oleoyl-LPA, AM095 (11\% activity) and Ki16425 (16\% activity), showed clear $\mathrm{LPA}_{1}$ antagonism. From the design strategy of our novel series we speculated that the isozaxole of AM095 was a spacer between an essential carbamate and biaryl acetic acid moieties. From this data it is now clear that isoxazole replacement is not tolerated in terms of $\mathrm{LPA}_{1}$ antagonism within this chemotype. However, it can be derivatized, as demonstrated by Qian et al triazole and pyrazole analogues. ${ }^{3}$ In parallel, the three series were evaluated for ATX inhibitory activity with bis-( $p$-nitrophenyl) phosphate as the substrate and PF-8380, a known ATX inhibitor, ${ }^{24}$ as the standard for comparison. As well as generating key developability data, ${ }^{28}$ $\left(\operatorname{logD},{ }^{25}\right.$ solubility, ${ }^{26}$ and permeability ${ }^{27}$ ) concentration-response (1 $\mathrm{nM}-30 \mu \mathrm{M})$ studies were performed to determine the potency of all 
compounds against ATX. ${ }^{28}$ The inhibitor constants (Ki) are summarized in Tables 1-4. To enable comparison with our progenitor hit compounds AM095 and Ki16245 were also tested as ATX inhibitors at $30 \mu \mathrm{M}$ and showed less than $20 \%$ ATX inhibition. Pleasingly, it was found that several of the compounds tested exhibited $\mathrm{K}_{\mathrm{i}}$ values less than $5 \mu \mathrm{M}(\mathbf{7 - 9}, \mathbf{2 0}, \mathbf{2 7}, \mathbf{3 4}, \mathbf{3 5}, \mathbf{3 7}, \mathbf{3 8}, \mathbf{4 3}$, and 44). The active compounds were all equipotent, however, varied significantly in their physicochemical profiles; solubility was generally high $(>100 \mu \mathrm{g} / \mathrm{mL})$, as measured by a high throughput solubility assay. However, permeability varied between the series, with the acyl aniline and indole compounds exhibiting increased membrane permeability, compared to those in the hydantoin series.

From the acyl aniline series it became evident that the presence of the acetic acid moiety was essential as its removal in compound $\mathbf{1 5}$ caused a complete loss of activity compared to compounds 7, 16, and 17. The acetic acid moiety is potentially binding to the $\mathrm{Zn}^{2+}$ ions present in the active site of ATX, an interaction that has been noted with other acidergic groups. ${ }^{29}$ An additional set of overlays were conducted, as illustrated in Scheme 7, with compounds 7, 15, 16 and 17 in order to rationalise the biological data which implied that the position of the acetic acid (-o, -m, or $-p)$ is not important, however, its presence is essential for activity. The overlay diagrams indicated that the backbone of all four compounds contained the same conformation. In terms of the three acetic acid moieties these all pointed in the same spacial orientation, indicating the potential beneficial interaction within the catalytic pocket. This would further support why its removal led to a complete loss of activity.

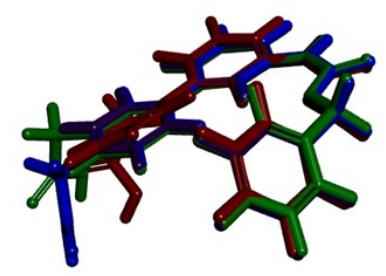

Scheme 7. Overlaid diagram of compounds 7 (blue), 15 (purple), 16 (red), and 17 (green) to illustrate the position of the acetic acid moiety.

It was also noted that substitution on the nitrogen of the aniline was tolerated, as illustrated by compound $\mathbf{2 5}$, with the introduction of a cyclohexyl group, and resulted in a $\mathrm{Ki}$ of $2 \mu \mathrm{M}$. However, the introduction of the tetrahydropyran (THP) group, compound 26, in this position was inactive, perhaps suggesting an unfavourable polar interaction with the oxygen present in the THP group which is absent in the cyclohexyl group. Thus, implying that other polar functionalities may also not be tolerated in this position.

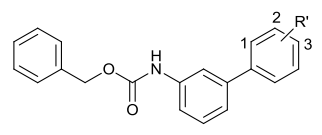

Table 1. Biological and Physicochemical Data for Acyl Aniline Series.

\begin{tabular}{|c|c|c|c|c|c|c|c|c|c|c|c|c|c|c|c|}
\hline Cpd. $^{\mathrm{a}}$ & $\mathrm{R}$ & $\begin{array}{l}\text { Pos } \\
\text { R' }^{\prime}\end{array}$ & $\mathrm{R}^{1}$ & $\begin{array}{c}\mathrm{Ki} \\
(\mu \mathrm{M})\end{array}$ & $\log D^{b}$ & $\begin{array}{c}\text { Sol. }^{\mathrm{c}} \\
(\mu \mathrm{g} / \mathrm{mL})\end{array}$ & $\begin{array}{c}\mathrm{P}_{\text {app }}{ }^{\mathrm{d}} \\
(\mathrm{nm} / \mathrm{s})\end{array}$ & abble & iolog & l an & d Physi & ca & $\mathrm{r} \mathrm{Hy}$ & antoin SeI & \\
\hline 15 & $\mathrm{H}$ & - & $\mathrm{H}$ & $>30$ & 7.52 & 5 & 450 & \multirow{2}{*}{ Cpd. $^{a}$} & \multirow{2}{*}{$\mathrm{R}$} & \multirow{2}{*}{$\mathrm{X}$} & \multirow{2}{*}{ Y } & \multirow{2}{*}{$\begin{array}{c}\mathrm{Ki} \\
(\mu \mathrm{M})\end{array}$} & \multirow{2}{*}{$\log D^{b}$} & \multirow{2}{*}{$\begin{array}{c}\text { Sol. }^{\mathrm{c}} \\
(\mu \mathrm{g} / \mathrm{mL})\end{array}$} & \multirow{2}{*}{$\begin{array}{r}\mathrm{P}_{\text {app }}{ }^{\mathrm{d}} \\
(\mathrm{nm} / \mathrm{s}) \\
\end{array}$} \\
\hline 16 & $\mathrm{H}$ & 1 & $\mathrm{CH}_{2} \mathrm{CO}_{2} \mathrm{H}$ & 4 & 3.06 & 287 & 140 & & & & & & & & \\
\hline 17 & $\mathrm{H}$ & 2 & $\mathrm{CH}_{2} \mathrm{CO}_{2} \mathrm{H}$ & 3.5 & 3.10 & 221 & 64 & 38 & $\mathrm{Ph}$ & $\mathrm{C}$ & $\mathrm{H}$ & 1.3 & 6.24 & 7.5 & 540 \\
\hline 7 & $\mathrm{H}$ & 3 & $\mathrm{CH}_{2} \mathrm{CO}_{2} \mathrm{H}$ & 4.5 & 3.19 & 198 & 73 & 9 & $\mathrm{Ph}$ & $\mathrm{C}$ & $\mathrm{CH}_{2} \mathrm{CO}_{2} \mathrm{H}$ & 3.6 & 2.18 & 174.5 & 3 \\
\hline & & & & & & & & 39 & $\mathrm{Ph}$ & $\mathrm{C}$ & $\mathrm{C}(c$-propyl) & $>30$ & 1.50 & 195 & 16 \\
\hline
\end{tabular}

${ }^{\mathrm{a}}$ Compound Number (Cpd), ${ }^{\mathrm{b}} \mathrm{Chrom} \log \mathrm{D}$ at $\mathrm{pH} 7.4$ (LogD), ${ }^{\mathrm{c}}$ Chemiluminescent nitrogen detection (CLND) kinetic aqueous solubility assay (Sol.), ${ }^{\mathrm{d}}$ Permeability $\mathrm{pH} 7.4$ assay $\left(\mathrm{P}_{\text {app }}\right)$.

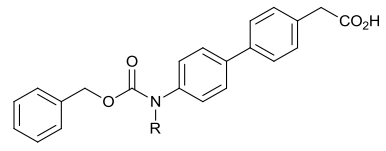

Table 2. Biological and Physicochemical Data for Substituted Acyl Aniline Series.

\begin{tabular}{cccccc}
\hline Cpd. $^{\text {a }}$ & $\mathrm{R}$ & $\mathrm{Ki}(\mu \mathrm{M})$ & $\operatorname{LogD}^{\mathrm{b}}$ & $\begin{array}{c}\mathrm{Sol}^{\mathrm{c}} \\
(\mu \mathrm{g} / \mathrm{mL})\end{array}$ & $\begin{array}{c}\mathrm{P}_{\text {app }}{ }^{\mathrm{d}} \\
(\mathrm{nm} / \mathrm{s})\end{array}$ \\
\hline $\mathbf{2 5}$ & $c$-Hex & 2 & 4.92 & 189 & 150 \\
$\mathbf{2 6}$ & THP & $>30$ & 3.13 & 212 & 23 \\
\hline
\end{tabular}

The aryl indole compounds, however, illustrated that the substitution of the biaryl ring was in fact important as moving the aryl carbamate from the 5 to the 6 position led to inactivity with $\mathrm{Ki}$ values of 1.1 and $>30 \mu \mathrm{M}$, respectively. Strikingly, this data implies that the acid moiety which was previously believed to be essential for activity is in fact not important therefore indicating a potential alternative hydrophobic binding mode.

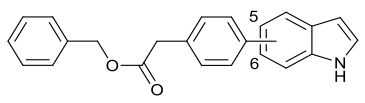

Table 3. Biological and Physicochemical Data for Aryl Indole Compounds.

\begin{tabular}{cccccc}
\hline Cpd. $^{\mathrm{a}}$ & Pos. & $\begin{array}{c}\mathrm{Ki} \\
(\mu \mathrm{M})\end{array}$ & $\log \mathrm{D}^{\mathrm{b}}$ & $\begin{array}{c}\text { Sol. } \\
(\mu \mathrm{g} / \mathrm{mL})\end{array}$ & $\begin{array}{c}\mathrm{P}_{\text {app }}{ }^{\mathrm{c}} \\
(\mathrm{nm} / \mathrm{s})\end{array}$ \\
\hline $\mathbf{8}$ & 5 & 1.1 & 7.25 & 70 & 445 \\
$\mathbf{3 2}$ & 6 & $>30$ & 7.43 & 110 & 510 \\
\hline
\end{tabular}

${ }^{\mathrm{a}}$ Compound Number (Cpd). ${ }^{\mathrm{b}}$ ChromlogD at $\mathrm{pH} 7.4 \quad(\operatorname{LogD})$.

${ }^{\mathrm{c}}$ Chemiluminescent nitrogen detection (CLND) kinetic aqueous solubility assay (Sol.). Permeability pH 7.4 assay $\left(\mathrm{P}_{\text {app}}\right)$.

Lastly, within the third series, phenyl substituted hydantoins with the presence or absence of an acetic acid moiety were active, $\mathbf{3 8}$ and $\mathbf{3 9}$ 1.3 and $3.6 \mu \mathrm{M}$, respectively, potentially indicating a different binding mode to both the acyl aniline and the aryl indole series. Surprisingly however, the addition of a cyclopropyl group adjacent to the acid group 36 rendered the compound inactive, potentially suggesting an unfavourable steric clash within the active site of the constrained and bulky cycloproply group. The isopropyl and cyclohexyl substituted hydantoins $(\mathbf{4 0}, 41,46$, and 47) all showed significant inhibitory activity of ATX with potencies in the range 1-4 $\mu \mathrm{M}$.

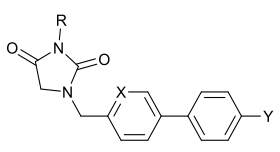




\section{$\mathrm{CO}_{2} \mathrm{H}$}

\begin{tabular}{cccccccc}
40 & $i-\mathrm{Pr}$ & $\mathrm{C}$ & $\mathrm{CH}_{2} \mathrm{CO}_{2} \mathrm{H}$ & 1.2 & 1.10 & 190 & 3 \\
$\mathbf{4 1}$ & $c-\mathrm{Hex}$ & $\mathrm{C}$ & $\mathrm{CH}_{2} \mathrm{CO}_{2} \mathrm{H}$ & 1.8 & 1.12 & 185.5 & 22 \\
$\mathbf{4 6}$ & $i$-Pr & $\mathrm{N}$ & $\mathrm{CH}_{2} \mathrm{CO}_{2} \mathrm{H}$ & 4 & -1.38 & 108 & $<10$ \\
$\mathbf{4 7}$ & $c-\mathrm{Hex}$ & $\mathrm{N}$ & $\mathrm{CH}_{2} \mathrm{CO}_{2} \mathrm{H}$ & 3.9 & -0.35 & 93 & $<30$ \\
\hline
\end{tabular}

${ }^{\mathrm{a}}$ Compound Number (Cpd), ${ }^{\mathrm{b}} \mathrm{Chrom} \log \mathrm{D}$ at $\mathrm{pH} 7.4$ (LogD),

${ }^{\mathrm{c}}$ Chemiluminescent nitrogen detection (CLND) kinetic aqueous solubility assay (Sol.), ${ }^{\mathrm{d}}$ Permeability $\mathrm{pH} 7.4$ assay $\left(\mathrm{P}_{\text {app }}\right)$.

To examine whether the inhibitors had an impact upon in-cell proliferation via ATX modulation, three of the prepared ATX inhibitors (7, 25, and 38) and AM095 were examined using a $\left[{ }^{3} \mathrm{H}\right]$ thymidine incorporation assay where the quantity of tritiated thymidine measured is proportional to DNA synthesis, as illustrated in Figure 2. There was a significant increase in DNA synthesis within PC3 cells when stimulated with LPA $(\mathrm{p}<0.05)$. Upon treatment with 7, 25, and $\mathbf{3 8}$ as well as AM095, DNA synthesis was inhibited to a statistically significant level $(\mathrm{p}<0.05)$ with respect to the control. Compounds 7, 25, 38 show ATX inhibitory potency and block baseline $\left[{ }^{3} \mathrm{H}\right]$-thymidine incorporation into PC3 cells, this suggests that the inhibitory effect is due to the compounds blocking the endogenous production of LPA by ATX. This can be rationalised by the fact that PC-3 cells express significant levels of endogenous autotaxin $^{30}$ that drives the generation of lysophophatidic acid (LPA) which in turn provides an autocrine / paracrine feedback loop to drive basal proliferation of these cells. Visual inspection of the cells showed no apparent cell death.
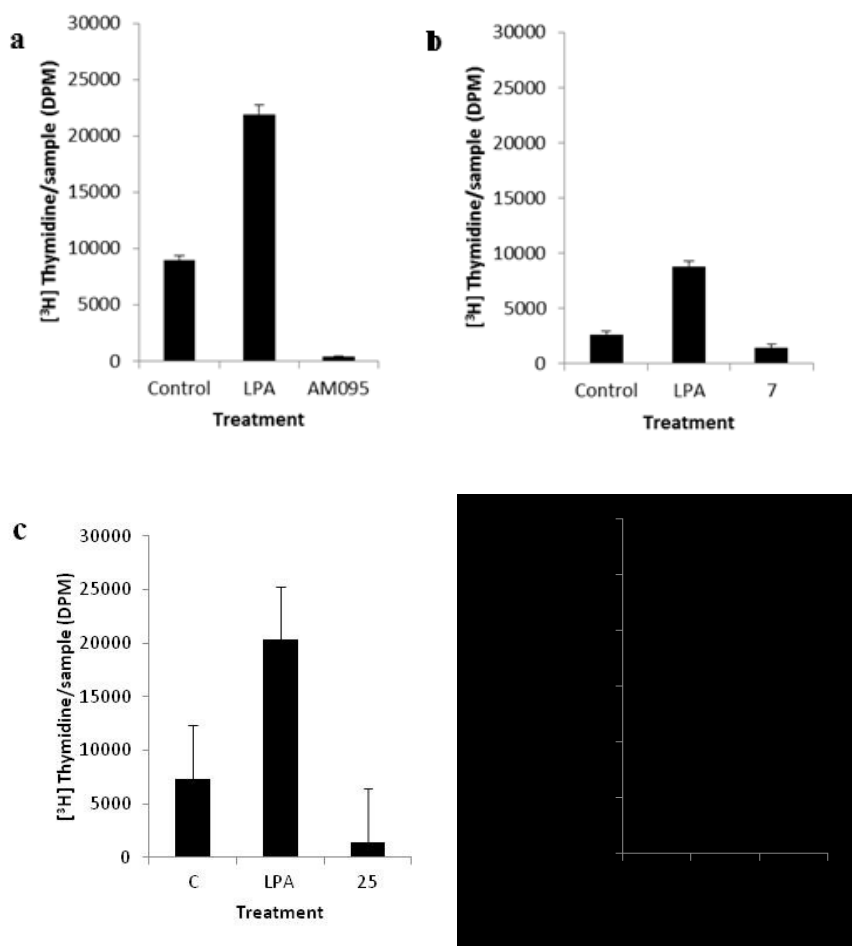

Figure 2. ${ }^{3} \mathrm{H}$-thymidine incorporation into LPA $(2 \mu \mathrm{M})$, AM095 (graph a), compound 7 (graph b), compound 25 (graph c), or compound 38 (graph d) $(10 \mu \mathrm{M})$, stimulated prostate cancer (PC3) cell line, cells were quiesced for 24 hours and treated for 18 hwith compounds (AM095, 7, 25, or 38). $\mathrm{n}=9$, data represented as Mean \pm S.E.M
Compounds 7, 25, and $\mathbf{3 8}$ were also tested for cytotoxicity in an A2780 ovarian cancer cell line at $30 \mu \mathrm{M}$ using an Alamar Blue ${ }^{\circledR}$ Assay. Gratifyingly, none of the compounds showed any signs of cytotoxicity.

\section{Conclusions}

Using a range of literature templates as a basis to design new compounds which could interact in the LPA-ATX signalling pathway, three novel chemotypes have been prepared and their inhibitor activities at LPA and ATX have been assessed. Although the compounds prepared did not show any activity against the $\mathrm{LPA}_{1}$ receptor, cross screening against ATX revealed that several exemplars had significant levels of inhibitory activity against the enzyme. Allied to this, measurements of the key developability parameters indicated that several of the hits identified had promising physicochemical profiles, suggesting that the series identified could offer potential for further optimisation. Efforts to achieve this are on-going and will be reported in due course.

\section{Acknowledgments}

We thank the EPSRC National Mass Spectrometry Service Centre, Swansea University for analyses and GlaxoSmithKline for funding. We thank Alan Hill for physicochemical analysis and Professor Susan Pyne and Professor Nigel Pyne at the Strathclyde Institute of Pharmacy and Biomedical Sciences.

\section{Notes and references}

${ }^{a}$ WestCHEM, Department of Pure and Applied Chemistry, University of Strathclyde, Thomas Graham Building, 295 Cathedral Street, Glasgow, G1 1XL, UK

${ }^{b}$ Strathclyde Institute of Pharmacy and Biomolecular Science, University of Strathclyde, John Arbuthnott Building (Hamnett Wing),161 Cathedral Street, Glasgow, G4 0RE, UK.

${ }^{c}$ Fibrosis DPU, GlaxoSmithKline, Medicines Research Centre, Gunnels Wood Road, Stevenage, Hertfordshire, SG1 2NY, UK.

1 A. Tokumura, E. Majima, Y. Kariya, K. Tominaga, K. Koqure, K. Yasuda, and K. Fukuzawa , J. Biol. Chem. 2002, 277, 39436-39442.

2 M. Umezu-Gomez, Y. Kishi, A. Taira, K. Hama, N. Dohmae, K. Takio, T. Yamori, G. B. Mills, K. Inoue, J. Aoki, and H. Arai, J. Cell Biol. 2001, 158, 227-233.

3 Y. Qian, M. Hamilton, A. Sidduri, S. Gabriel, Y. Ren, R. Peng, R. Kondru, A. Narayanan, T. Truitt, R. Hamid, Y. Chen, L. Zhang, A. J. Fretland, R. A. Sanchez, K. C. Chang, M. Lucas, R. C. Schoenfeld, D. Laine, M. E. Fuentes, C. S. Stevenson, and D. C. Budd, J. Med. Chem. 2012, 55, 7920-7939.

4 K.Nakanaga, K. Hama, and J. Aoki, J. Biochem., 2010, 148, 13-24

5 L. Federico, Z . Pamuklar, S.S. Smyth, and A.J. Morris, Curr Drug Targets. 2008, 9, 698-708.6S. G. Bourgion, and C. Zhao, Curr. Opin. Investig. Drugs 2010, 11, 515-526.

7 S. Willier, E. Butt, and T. G. Grunewald, Biol. Cell. 2013, 105, $317-$ 333.

8 A. M Tager, P. LaCamera, B. S. Shea, G. S. Campanella, M. Selman, Z. Zhao, V. Polosukhin, J. Wain, B. A. Karimi-Shah, N. D. Kim, W. K. Hart, A. Pardo, T. S. Blackwell, Y. Xu, J. Chun, and A. D. Luster, Nature Med. 2008, 14, 45-54.

9 Y. Zhao and V. Natarajan, Biochim. Biophys. Acta. 2013, 1831, 8692.

10 J. Chun, T. Hla, S. Spiegel, and W. Moolenarr, Lysophospholipid Receptors Signalling and Biochemistry, Wiley, Hoboken, 2013.

11 A. F. Abdel-Magid, ACS Med. Chem. Lett. 2014, 5, 1072-1073.

12 Y. Kihara, H. Mizuno, and J. Chun, Exp. Cell. Res. 2014, DOI: 10.1016/j.yexcr.2014.11.020

13 J. Fischer, N. Nusser, T. Virag, K. Yokoyama, D. Wang, D. L. Baker, D. Bautista, L. Parrill, and G. Tigyi, Mol. Pharmacol. 2001, 60, 776784. 
14 C. E. Heise, W. L. Santos, M. Schreihofer, B. H. Heasley, Y. V Mukhin, T. L. Macdonald, and K. R. Lynch, Mol. Pharmacol. 2001, 60, 1173-1180.

15 D. D. Miller, G. Tigyi, V. Gududura, Y. Fujiwara, D. Baker, M. D. Walker, and G. Durgam, US2006270634A1, 2006.

16 H. Zhang, X. Xu, J. Gajewiak, R. Tsukahara, Y. Fujiwara, J. Liu, J. I. Fells, D. Perygin, A. L. Parrill, G. Tigyi, and G. D. Prestwich, Cancer Res. 2009, 69, 5441-5449.

17 T. J. Ritchie and S. J. F. Macdonald, Drug Discov. Today, 2009, 14, 1011-1020.

18 H. Ohta, K. Sato, N. Murata, A. Damirin, E. Malchinkhuu, J. Kon, T. Kimura, M. Tobo, Y. Yamazaki, T. Watanabe, M. Yagi, M. Sato, R. Suzuki, H. Murooka, T. Sakai, T. Nishitoba, D. S. Im, H. Nochi, K. Tamoto, H. Tomura, and F. Okajima, Mol. Pharmacol. 2003, 64, 994-1005.

19 M. M. Hann and T. I. Oprea, Curr. Opin. Chem. Biol. 2004, 8, 255263.

20 M. J. Frisch, G. W. Trucks, H. B. Schlegel, G. E. Scuseria, M. A. Robb, J. R. Chesseman, G. Scalmani, V. Barone, B. Mennucci, G. A. Petersson, H. Nakatsuji, M. Caricato, X. Li, H. P. Hratchian, A. F. Izmaylov, J. Bloino, G. Zheng, J. L. Sonnenberg, M. Hada, M. Ehara, K. Toyota, R. Fukuda, J. Hasegawa, M. Ishida, T. Nakajima, Y. Honda, O. Kitao, H. Nakai, T. Vreven, J. A. Montgomery, J. E. Peralta, F. Ogliara, M. Bearpark, J. J. Heyd, E. Brothers, K. N. Kudon, V. N. Staroverov, R. Kobayashi, J. Normand, K. Raghavachari, A. Rendell, J. C. Burant, S. S. Iyengar, J. Tomasi, M. Crossi, N. Rega, J. M. Millam, M. Klene, J. E. Know, J. B. Cross, V. Bakken, C. Adamo, J. Jaramillo, R. Gomperts, R. E. Stratmann, O. Yazyev, A. J. Austin, R. Cammi, C. Pomelli, J. W. Ochterski, R. L. Martin, K. Morokuma, V. G. Zakrzewski, G. A. Voth, P. Salvador, J. J. Dannenberg, S. Dapprich, A. D. Daniels, O. Farkas, J. B. Foresman, J. V Ortiz, J. Cioslowski, and D. J. Fox, Gaussian 09, Revis. A.02, 2009.

21 Accelrys Software Inc., Discovery Studio Modelling Environment, Release 4.0, San Diego: Accelrys Software Inc., 2013.

22 T. J. Ritchie and S. J. F. Macdonald, Drug Discov. Today, 2009, 14, 1011-1020.

23 See the Supporting Information for full details.

24 W. H. Moolenaar, A. Perrakis, Nat. Rev. Mol. Cell. Biol.,2011, 12, 674-679.

25 R. J. Young, D. V. S. Green, C. N. Luscombe, A. P. Hill, Drug Discov. Today 2011, 16, 822-830

26 E. H. Demont, P. Bamborough, C. W. Chung, P. D. Craggs, D. Fallon, L. J. Gordon, P. Grandi, C. I. Hobbs, J. Hussain, E. J. Jones, A. Le Gall, A. M. Michon, D. J. Mitchell, R. k. Prinjha, A. D. Roberts, R. J. Sheppard, and R. J. Watson, ACS Med. Chem. Lett., 2014, 5, 11, 1190-1195

27 K. Valko K, S. Nunhuck C. Bevan, M. H. Abraham, D. P. Reynolds, J. Pharm. Sci. 2003, 92, 2236-2248.

28 See the Supporting Information for full details.

29 H. M. H. G. Albers, L. J. D. Hendrickx, R. J. P van Tol, J. Hausmann, A. Perrakis, H. Ovaa, J. Med. Chem. 2011, 54, 46194626.

30 M. A. A. M. Nouh, X. X. Wu, H. Okazoe, H. Tsunemori, R. Haba, A. M. M, Abou-Zeid, M. D. Saleem, M. Inui, M. Sugimoto, J. Aoki, Y. Kakehi, Cancer Sci. 2009, 100, 1631-1639. 